\title{
PENGEMBANGAN PENDIDIKAN ISLAM DENGAN IMPLIKASI TEKNOLOGI PENDIDIKAN
}

\author{
Nasruddin Hasibuan \\ Lecturer of Tarbiyah and Teacher Training at IAIN Padangsidimpuan \\ Jl. T. Rijal Nurdin Km.4,5 Sihitang Padangsidimpuan 22733 \\ Email: nasruddin.iain@gmail.com
}

\begin{abstract}
This paper aims to determine how the development of Islamic education with implications for educational technology. Writing method uses library research methods. From the discussion, it can be concluded that the development of modern technology or information technology spur a new way of life, of life begins to come to an end, this life is known as e-life, meaning of life has been influenced by a variety of electronic needs.
\end{abstract}

Keywords: Islamic Education, and Education Technology.

\begin{abstract}
Abstrak
Artikel ini bertujuan untuk mengetahui perkembangan pendidikan Islam dengan implikasi teknologi pendidikan. Metode penulisan menggunakan metode diskusi pustaka. Dari diskusi, dapat disimpulkan bahwa perkembangan teknologi modern atau teknologi informasi memacu suatu cara baru dalam kehidupan, dari dimulainya kehidupan sampai berakhir, kehidupan ini dikenal sebagai elektronik kehidupan, makna hidup telah dipengaruhi oleh berbagai kebutuhan elektronik.
\end{abstract}

Kata Kunci: Pendidikan Islam, dan Teknologi Pendidikan.

\section{PENDAHULUAN}

Memasuki abad Teknologi Informasi dan Komunikasi sekarang ini sangat dirasakan kebutuhan akan pentingnya peningkatan kualitas pembelajaran. Melalui pemanfaatan teknologi pendidikan kita dapat meningkatkan kualitas pembelajaran, yaitu dengan cara membuka lebar-lebar terhadap akses ilmu pengetahuan dan penyelenggaraan pendidikan bermutu. Terutama penerapan high tech dan high touch approach. System teknologi informasi dalam pendidikan memberi jangkauan yang luas, cepat, efektif, dan efisien terhadap penyebarluasan informasi ke berbagai penjuru dunia. Teknologi informasi berkembang sejalan dengan perkembangan teori komunikasi dan teknologi yang menunjang terhadap praktek kegiatam pembelajaran. Pembelajaran berbasis multimedia seperti : pembelajaran berbaris komputer (PBK), pembelajaran berbaris web (e-learning), merupakan bentuk pemanfaatan TIK yang perlu dilaksanakan dalam dunia pendidikan dewasa ini. ${ }^{1}$

Kegiatan pembelajaran merupakan kegiatan yang paling pokok dalam keseluruhan

${ }^{1}$ SudjarwoTeknologi Pendidikan. (Surabaya : Erlangga, 1984.), hlm. 12. 
proses pendidikan. Hal ini berarti bahwa pencapaian tujuan pendidikan banyak bergantung kepada proses pembelajaran dirancang dan dijalankan secara professional, seperti saat ini, dengan dimanfaatkannya Teknologi Informasi dan Komuniksi, khususnya computer dan internet dirasa sangat membantu dalam kegiatan pembelajaran. ${ }^{2}$

Salah satu permasalahan pendidikan yang menjadi prioritas untuk segera dicari pemecahannya adalah masalah kualitas pendidikan, khususnya kualitas pembelajaran. Dari berbagai kondisi dan potensi yang ada, upaya yang dapat dilakukan berkenaan dengan peningkatan kualitas pendidikan ialah dengan mengembangkan teknologi pembelajaran yang berorientasi pada interest peserta didik dam memfasilitasi kebutuhan pengembangan kognitif, efektif dan psikomotornya.

Seiring dengan perkembangan teknologi pendidikan beserta infrastruktur penunjangnya, upaya peningkatan mutu pendidikan di atas antara lain dapat dilakukan melalui pemanfaatan teknologi pendidikan tersebut dalam kegiatan pembelajaran. Teknologi pendidikan merupakan suatu system yang dapat memfasilitasi pendidik dan peserta didik belajar lebih luas, lebih banyak dan juga bervariasi. Melalui fasilitas yang disediakan oleh system tersebut, siswa dapat belajar mandiri, kapan dan dimana saja tanpa terbatas oleh ruang dan waktu. Bahan yang dapat mereka pelajari juga lebih bervariasi, tidak hanya dalam bentuk sajian kata, tetapi dapat lebih kaya dengan varisi teks, visual, audio dan animasi.

Untuk itu sudah selayaknyalah pada pendidik harus mampu menciptakan kondisi pembelajaran yang humanis, yaitu kondisi pembelajaran yang menyenangkan dengan mengoptimalkan peran teknologi pembelajaran khususnya untuk pendidikan Islam.

Penulisan makalah ini bertujuan untuk mengetahui bagaimana pengembangan pendidkan Islam dengan implikasi teknologi pendidikan.

\section{KAJIAN PUSTAKA}

\section{Pengertian Teknologi Pendidikan}

Teknologi pendidikan adalah kajian dan praktik untuk membantu proses belajar dan meningkatkan kinerja dengan membuat, menggunakan, dan mengelola proses dan sumber teknologi yang memadai. Istilah teknologi pendidikan sering dihubungkan dengan teori belajar dan pembelajaran. Bila teori belajar dan pembelajaran mencakup proses dan sistem dalam belajar dan pembelajaran, teknologi pendidikan mencakup sistem lain yang digunakan dalam proses mengembangkan kemampuan manusia. ${ }^{3}$

Teknologi pendidikan merupakan suatu proses yang kompleks dan terpadu melibatkan orang, prosedur, peralatan, dan organisasi untuk menganalisis masalah,

\footnotetext{
${ }^{2}$ Asmani, Ma'mur, Teknologi Informasi dan Komunikasi dalam Dunia Pendidikan. (Jogjakarta : Diva Press, 2011), hlm. 5.

3 AECT, The Definition Of Educational Technology. (Washington, D.C., USA: Association for Educational Communications and Technology, 2004) hlm. 6.
} 
mencari jalan pemecahan masalah yang menyangkut semua aspek belajar manusia. Educational technology is the study and ethical practice of facilitating learning and improving performance by creating, using, and managing appropriate technological processes and resources. ${ }^{4}$

Alat-alat teknologi pendidikan dapat mengubah peranan guru. Alat-alat teknologi akan mempermudah guru dalam penyampaian pesan dalam proses pembelajaran. Namun peranan guru tidak akan dapat ditiadakan dan akan selalau diperlukan. Mengawinkan "teknologi' dengan "pendidikan" dapat mengejutkan profesi guru, sebab teknologi diasosiasikan dengan mesin yang dapat menimbulkan bahaya "dehumanisasi" pendidikan, yaitu pendidikan yang "mechanical" yang serba mesin, yang menghilangkan unsur manusiawi yang selalu terdapat dalam interaksi sosial antara guru dan murid dan antara murid dan pelajaran.

Pengalaman dengan alat teknologi pendidikan membuktikan bahawa dalam proses belajar-mengajar guru tetap memegang peranan penting. Macam-macam teknologi pendidikan menurut Davies ada tiga yaitu:

a. Teknologi pendidikan satu.

Teknologi pendidikan satu yaitu mengarah pada perangkat keras seperti proyektor, laboratorium, komputer (CD ROM, LCD, TV, Video dan alat elektronik lainnya). Teknologi mekanik ini dapat mengotomatiskan proses belajar mengajar dengan alat yang memancarkan, memperkuat suara, mendistribusikan, merekam dan mereproduksi stimuli material yang menjangkau pendengar/ siswa dalam jumlah yang besar. Jadi teknologi satu ini efektif dan efisien. ${ }^{5}$

b. Teknologi pendidikan dua

Teknologi pendidikan dua mengacu pada "perangkat lunak" yaitu menekankan pentingnya bantuan kepada pengajaran. Terutama sekali dalam kurikulum, dalam pengembangan instruksional, metodologi pengajaran, dan evaluasi. Jadi teknologi dua, menyediakan keperluan bagaimana merancang yang baru atau memperbarui yang sekarang, bermanfaat pada pengalaman belajar Mesin dan mekanisme dipandang sebagai instrumen presentasi atau transmisi.

c. Teknologi pendidikan tiga

Teknologi pendidikan tiga, yaitu kombinasi pendekatan dua teknologi yaitu "peragkat keras" dan perangkat lunak". Teknologi pendidikan tiga, orientasi utamanya yaitu ke arah pendekatan sistem, dan sebagai alat meningkatkan manfaat dari apa yang ada di sekitar. Teknologi pendidikan tiga dapat dikatakan sebagai pendekatan pemecahan masalah, titik beratnya dalam orientasi diagnostik yang menarik.

Dari ketiga macam tekonologi di atas dapat dikatakan bahwa teknologi pendidikan

\footnotetext{
${ }^{4}$ Ibid

${ }^{5}$ Nasution, N. Teknologi Pendidikan (Jakarta : Bumi Aksara, 2008) hlm. 45.
} 
dalam konteks sebenarnya adalah tidak hanya mengacu pada perangkat keras saja seperti yang umum dijadikan sebagai persepsi yang benar, namum juga meliputi perangkat lunak dan perpaduan keduanya perangkat keras dan lunak.

Miarso Yusufhadi menjelaskan bahwa teknologi pendidikan dapat didefenisikan kemampuannya dengan dua cara; Pertama dengan melakukan pengkajian empirik, dan kedua dengan melakukan analisis konseptual. Adapun The National Task Force on Educational Technology melaporkan hasil pengkajiannya tentang kegunaan teknologi pendidikan sebagai berikut: 6

a. Mengembangkan pengetahuan dan keterampilan dasar yang efesien dari cara-cara konvensional;

b. Mengajarkan konsep dan keterampilan penalaran pada peringkat tinggi yang sulit dikembangkan tanpa bantuan teknologi;

c. Mengembangkan pemehaman tentang teknologi informasi serta kegunaanya bagi masyarakat dan dunia kerja;

d. Memungkinkan guru untuk mengelola lingkungan belajar, dimana belajar dirancang untuk memenuhi kebutuhan dan kemampuan masing-masing siswa, serta kemampuan mereka untuk mencapai penguasaan yang dipreskripsikan;

e. Mengembangkan keterampilan dalam menggunakan komputer dan teknologi lain yang berkaitan.

\section{Disiplin Keilmuan Teknologi Pendidikan}

Terlebih dahulu perlu diberikan batasan umum tentang pengertian teknologi, semua teknologi termasuk teknologi pendidikan, yaitu :

a. proses yang meningkatkan nilai tambah;

b. produk yang digunakan dan/atau dihasilkan untuk memudahkan dan meningkatkan kinerja;

c. struktur atau sistem dimana proses dan produk itu dikembangkan dan digunakan.

Teknologi memasak misalnya, adalah proses untuk mengolah bahan mentah (sayuran, tahu, tempe, daging, garam, bumbu dsb.) dengan menggunakan produk berupa pisau, wajan, panci, kompor dsb. untuk menghasilkan produk berupa makanan, dan makanan itu sendiri merupakan komponen dari sistem kelangsungan hidup berupa gizi atau nutrisi, yang perlu dilengkapi dengan komponen lain seperti minum, olahraga, istirahat dsb.

Teknologi pendidikan telah berkembang sebagai suatu disiplin keilmuan yang berdiri sendiri. Perkembangan tersebut dilandasi oleh serangkaian kaidah atau dasar yang dijadikan patokan pembenaran. Secara falsafi, dasar keilmuan itu meliputi: ontologi atau rumusan tentang obyek formal atau pokok telaah yang merupakan gejala

${ }^{6}$ Miarso, Yusufhadi, Menyemai Benih Teknologi Pendidikan. Jakarta : Pustekkom bekerjasama dengan Kencana, 2004) hlm. 66. 
pengamatan yang tidak tergarap oleh bidang telaah lain; epistemologi yaitu usaha atau prinsip intelektual untuk memperoleh kebenaran dalam pokok telaah yang ditentukan; dan aksiologi atau nilai-nilai yang menentukan kegunaan dari pokok telaah yang ditentukan, yang mempersoalkan nilai moral atau etika dan nilai seni dan keindahan atau estetika.

Obyek formal teknologi pendidikan adalah belajar pada manusia. Belajar itu sendiri dapat diartikan sebagai perubahan pada diri seseorang atau suatu lembaga yang relatif menetap dan berkembang dalam pengetahuan, sikap dan keterampilan, yang disebabkan karena pemikiran dan pengalaman. Belajar itu terjadi dimana saja, kapan saja, apa saja, dari apa atau siapa saja, dan dengan cara bagaimana saja. Gambar berikut menunjukkan obyek formal tersebut.

Sedang gejala yang memerlukan penggarapan terhadap obyek formal tersebut adalah :

a. Adanya sejumlah besar orang yang belum terpenuhi kesempatan belajarnya, baik yang diperoleh melalui suatu lembaga khusus, maupun yang dapat diperoleh secara mandiri

b. Adanya berbagai sumber belajar baik yang telah tersedia maupun yang dapat direkayasa, tetapi belum dapat dimanfaatkan untuk keperluan belajar.

c. Diperlukan adanya suatu usaha khusus yang terarah dan terencana untuk menggarap sumber-sumber tersebut agar dapat terpenuhi hasrat belajar setiap orang sesuai dengan kebutuhan dan kondisi lingkungan.

d. Diperlukan adanya pengelolaan atas kegiatan khusus dalam mengembangkan dan memanfaatkan sumber untuk belajar tersebut secara efektif, efisien dan selaras.

Usaha khusus yang terarah dan terencana bukan sekedar menambah yang kurang, menambal yang berlubang, dan menjahit yang sobek. Menurut Banathy bukan hanya "doing more of the same", ataupun "doing it better of the same", melainkan "doing it differently" yaitu merupakan upaya untuk menjamin hasil yang diharapkan. Pendekatan yang berbeda itu adalah pendekatan yang memenuhi lima persyaratan, yaitu :7

a. Pendekatan isomeristik, yaitu yang menggabungkan berbagai kajian/bidang keilmuan (psikologi, komunikasi, ekonomi, manajemen, rekayasa teknik dsb.) ke dalam suatu kesatuan tersendiri;

b. Pendekatan sistematik, yaitu dengan cara yang berurutan dan terarah dalam usaha memecahkan persoalan;

c. Pendekatan sinergistik, yaitu yang menjamin adanya nilai tambah dari keseluruhan kegiatan dibandingkan dengan bila kegiatan itu dijalankan sendiri-sendiri, dan

d. Sistemik, yaitu pengkajian secara menyeluruh.

e. Inovatif, yaitu mencari dan mengembangkan solusi yang baru

${ }^{7}$ Banathy, Bela H. 1991. System Design in Education : a journey to create the future. Englewood Cliffs, $\mathrm{NJ}$ : Educational Technology Publications, hlm. 56. 
Usaha khusus dengan pendekatan inilah yang merupakan azas epistemologi teknologi pendidikan. Azas manfaat atau aksiologi dari teknologi pendidikan dapat dinyatakan dengan kutipan pendapat Menteri Pendidikan dan Kebudayaan Daoed Joesoef dalam Lokakarya Nasional Teknologi Pendidikan di Yogyakarta pada tahun 1982 sebagai berikut :

"Teknologi pendidikan perlu dipikirkan dan dibahas terus menerus karena adanya kebutuhan real yang mendukung pertumbuhan dan perkembangannya, yaitu (i) tekad mengadakan perluasan dan pemerataan kesempatan belajar; (ii) keharusan meningkatkan mutu pendidikan berupa, antara lain, penyempurnaan kurikulum, penyediaan berbagai sarana pendidikan, dan peningkatan kemampuan tenaga pengajar lewat berbagai bentuk pendidikan serta latihan; (iii) penyempurnaan system pendidikan dengan penelitian dan pengembangan sesuai dengan tantangan jaman dan kebutuhan pembangunan; (iv) peningkatan partisipasi masyarakat dengan pengembangan dan pemanfaatan berbagai wadah dan sumber pendidikan; (v) penyempurnaan pelaksanaan interaksi antara pendidikan dan pembangunan di mana manusia dijadikan pusat perhatian pendidikan."

Pernyataan kebijakan tersebut pada saat ini telah terwujutkan, baik sebagai konsep maupun sebagai bentuk atau pola pelembagaan pendidikan. Konsep tersebut bahkan telah dikukuhkan dengan ketentuan perundangan dan peraturan. Paling tidak ada lima konsep dalam teknologi pendidikan yang telah terintegrasi dalam sistem pendidikan dan tertuang dalam Undang-undang Sisdiknas dan turunannya. Ke lima konsep itu adalah : 1) pembelajaran yang berfokus pada peserta didik; 2) sumber belajar yang beraneka; 3) pendekatan dari bawah (bottom-up approaches) dalam mengelola kegiatan belajar dan implikasinya dalam satuan pendidikan; 4) sistem pendidikan terbuka dan multi makna; dan 5) pendidikan jarak jauh.

Namun perlu diperhatikan bahwa pembenaran secara falsafi, harus dilengkapi dengan pembenaran ilmiah. Pembenaran ilmiah dilakukan dengan melalui tiga kategori pendekatan yang berakar pada filsafat ilmu. Ke tiga pendekatan itu ialah pengembangan, penelitian, dan penilaian yang diperlukan untuk menghasilkan teori, model, sistem, pembuktian, program aksi, dan kebijakan. Kebenaran ilmiah dalam disiplin teknologi pendidikan telah dan sedang dilakukan untuk mengembangkan model, produk dan sistem, pengujian berbagai strategi dan media pembelajaran, serta berbagai penilaian seperti penelusuran kebutuhan, penilaian efektivitas tindakan dan sebagainya.

Perlu disadari bahwa semua bentuk teknologi, termasuk teknologi pendidikan, adalah sistem yang diciptakan oleh manusia untuk sesuatu tujuan tertentu, yang pada intinya adalah mempermudah manusia dalam memperingan usahanya, meningkatkan hasilnya, dan menghemat tenaga serta sumber daya yang ada. Oleh karena itu teknologi itu pada hakekatnya adalah tidak bebas nilai, karena terkandung adanya aturan etik dan estetika dalam penciptaa dan penggunaannya. Namun ada orang-orang tertentu yang menyalahgunakan makna dan/atau penggunaannya, dengan menganggap teknologi itu 
value-free atau empty of meaning.

Bertolak dari landasan filsafat dan pembenaran ilmiah tersebut di atas, teknologi pendidikan di definisikan sebagai teori dan praktek dalam merancang mengemangkan, menerapkan, mengelola, menilai dan meneliti proses, sumber dan sistem belajar.

\section{Teknologi Pendidikan dalam Pembelajaran}

Proses belajar mengajar itu sendiri berintikan kegiatan belajar, dalam arti proses belajar mengajar harus mampu mengupayakan bagaimana siswa belajar. Karena inti dari proses belajar mengajar adalah siswa belajar, maka efektivitasnya sangat bergantung pada efektivitas siswa dalam belajar. Demikian pentingnya kegiatan belajar, sehingga Muhibbin Syah mengemukakan bahwa tanpa belajar tak pernah ada pendidikan, karena bagian terbesar proses pendidikan adalah diarahkan pada tercapainya proses perubahan pada diri manusia.

Efektivitas proses belajar menekankan pada suatu usaha yang akan melahirkan aktivitas belajar yang efektif. Belajar yang efektif pada hakekatnya merupakan suatu aktivitas belajar yang optimal pada diri siswa.

Penerapan strategi belajar mengajar yang menekankan pada keefektifan siswa dalam belajar, akan menyebabkan siswa dapat menggunakan seluruh kemanpuan dasar yang dimilikinya untuk melakukan berbagai kegiatan belajar yang dipersyaratkan.

Pengajaran dari sudut Proses (by Procee), ialah suatu pengajaran dikategorikan efektif jika pengajaran itu berlangsung secara interaktif yang dinamis sehingga memungkinkan siswa dapat mengembangkan potensinya melalui kegiatan belajar berdasarkan tujuan yang telah ditetapkan. Sedangkan pengajaran dari sudut hasil (by Product), adalah suatu pengajaran dikatakan efektif jika siswa dapat mewujudkan tujuan pengajaran baik dari segi kualitas maupun kuantitasnya.

Mengkaji kriteria tersebut di atas, menunjukkan bahwa pengajaran yang efektif menitikberatkan pada penciptaan aktivitas belajar siswa seoptimal mungkin. Guru harus selalu berusaha menfasilitasi atau menciptakan kondisi yang kondusif agar siswa dapat belajar secara aktif atas kesadaran dan kemauannya sendiri.

Efektifitas pendidikan dan pengajaran sering diukur dengan tercapainya tujuan yang telah ditentukan sebelumnya. Pengertian ini mengandung pokok pikiran bahwa pendidikan dan pengajaran haruslah:

a. Bersistem (sistematis), yaitu penyelenggaraan pendidikan dan pengajaran secara sistematis, mulai dari tahap perencanaan, pengembangan, pelaksanaan, penilaian, dan penyempurnaan.

b. Sensitif terhadap kebutuhanakan tugas belajar dan kebutuhan pembelajaran

c. Jelas tujuannya dan kerena itu dapat dihimpun usaha untuk mencapainya.

d. Bertolak dari kemampuan atau kekuatan mereka yang bersangkutan yakni; peserta didik, pendidik, masyarakat dan pemerintah. 
Untuk menunjang proses pembelajaran yang efektif maka teknologi pendidikan sangat diperlukan karena dalam prakteknya teknologi pendidikan memiliki andil yang besar dalam dunia pembelajaran modern, berkaitan dengan hal diatas prinsip yang melandasi teknologi pendidikan dalam proses pembelajaran sekurang - kurangnya ada 5 yaitu:

a. Teknologi pendidikan sebagai usaha memperoleh tingkah laku

b. Hasil belajar siswa ditandai dengan perubahan tingkah laku secara keseluruhan

c. Pembelajaran merupakan suatu proses

d. Proses pembelajaran terjadi karena adanya suatu dorongan dan tujuan yang akan dicapai

e. Pembelajaran merupakan bentuk pengalaman

Dari uraian di atas maka dalam pembelajaran yang baik dalam konteks teknologi pendidikan, media atau alat pembelajaran memiliki nilai manfaat bagi guru maupun murid karena cukup efektif dan efisien dalam upaya pencapaian kompetensi yang diharapkan. Media atau alat-alat pembelajaran tersebut seperti radio, televisi, laptop, internet, LCD dan lainnya baik yang bersifat sederhana maupun modern sangat membantu keefektifan proses pembelajaran. Pembelajaran berbasis teknologi pendidikan akan berjalan sangat efektif jika guru menerapkan model pembelajaran berpusat pada siswa (student centered).

Dalam proses / konsep teknologi pendidikan, tugas media atau alat bukan hanya sekedar mengkomunikasikan hubungan antara sumber (pengajar) dan sipenerima (si anak didik), namun lebih dari itu merupakan bagian yang integral dan saling mempunyai keterkaitan antara komponen yang satu dengan yang lainnya, saling berinteraksi dan saling mempengaruhi.

\section{Kontribusi Teknologi Pendidikan}

Berdasarkan uraian di atas, kontribusi teknologi pendidikan dalam pembangunan pendidikan dapat dibedakan dalam tiga kategori, yaiitu konsep, tenaga profesi dan kegiatan. Dalam pembahasan tentang azas manfaat teknologi pendidikan sebagai disiplin keilmuan telah dikemukakan bahwa teknologi pendidikan telah menyumbangkan sedikitnya lima konsep dalam pembaharuan sistem pendidikan nasional. Istilah dan konsep "pembelajaran" telah diciptakan dan digunakan dalam kalangan teknologi pendidikan sejak tahun 1978. Istilah itu pada awalnya dihiraukan bahkan dicibirkan oleh banyak kalangan pendidikan lain. Namun dalam UU Sisdiknas 2003, istilah dan konsep tersebut dikukuhkan sebagai sebuah keharusan dalam proses pendidikan. Pengertian "pembelajaran" dalam UU Sisdiknas adalah "proses interaksi peserta didik dengan pendidik dan sumber belajar dalam lingkungan belajar". Sedangkan dalam konsep teknologi pendidikan, saya mendefinisikannya sebagai "proses sistematik dan sistemik 
yang dilakukan oleh seseorang atau sekelompok orang agar orang lain dapat secara aktif belajar sehingga mencapai kompetensi yang diharapkan."

Penggunaan istilah "pembelajaran" bukan sekedar penggantian istilah "pengajaran". Berdasarkan Penjelasan PP No. 19 Tahun 2005 tentang Standar Nasional Pendidikan, dinyatakan bahwa paradigma pengajaran yang lebih menitikberatkan peran pendidik dalam mentransfomasikan pengetahuan bergeser pada paradigma pembelajaran yang memberikan peran lebih banyak kepada peserta didik untuk mengembangkan potensi dan kreativitas dirinya. Adapun visi teknologi pendidikan yang dirumuskan pada tahun 1987 telah terfokus kepada kepentingan peserta didik dengan rumusan "terciptanya kondisi yang memungkinkan setiap orang berkembang potensinya secara optimal, dengan dikembangkan dan dimanfaatkannya berbagai strategi dan sumber belajar". Fokus kepada pemelajar tersebut telah merupakan kepedulian dalam kalangan teknologi pendidikan, dan dituangkan sebagai perubahan paradigma teknologi pendidikan yang ketiga pada tahun 1977.8

Penetapan standar proses sebagai salah satu standar nasional pendidikan, dapat dikatakan merupakan implementasi dari konsep teknologi pendidikan sebagai proses untuk memperoleh nilai tambah. Langkah-langkah dalam standar proses yang meliputi perencanaan, pelaksanaan, penilaian dan pengawasan juga identik dengan proses pembelajaran dalam konsep teknologi pendidikan. Demikian pula istilah dan konsep tentang sumber belajar, pendidikan terbuka dan multi makna, manajemen berbasis sekolah (yang merupakan pendekatan bottom-up), dan pendidikan jarak jauh, saya yakin merupakan kontribusi dari konsep teknologi pendidikan.

Kontribusi tenaga profesi, baik akademisi maupun praktisi, dalam pembangunan pendidikan tidak diragukan lagi. Para profesi tersebut pada saat ini telah menyebar di dalam maupun ke luar lingkungan pendidikan, yaitu pada lembaga pelatihan, lembaga pemerintahan, dan lembaga masyarakat, lembaga media massa (radio, televisi dan surat kabar), serta lembaga atau organisasi bisnis dan industri yang berniat menjadi organisasi belajar. Mereka berkarya dalam berbagai bidang yang berkaitan dengan belajar dan biasanya bekerja dalam satuan regu dengan aneka tugas, seperti perancang pembelajaran, artis grafis, ahli media, ahli evaluasi, pemrogram komputer, dan lain sebagainya. Para gurupun sebagian telah menjadi praktisi teknologi pendidikan, yaitu dengan menerapkan kawasan pemanfaatan dalam konsep teknologi pendidikan.

Lembaga penyelenggara pendidikan profesi teknologi pendidikan sekarang ini ada di mana-mana, dan telah berkembang sebagai suatu jaringan. Penyelenggaraan program akademik sekarang ini telah tersebar sedikitnya di 37 perguruan tinggi negeri maupun

${ }^{8}$ AECT, The Definition Of Educational Technology...., 2004, hlm. 108. 
swasta, delapan di antaranya menyelenggarakan pendidikan hingga jenjang Magister, dan tiga pada jenjang Doktor.

Kontribusi berupa kegiatan, terwujud dengan tumbuh dan berkembangnya berbagai pola pendidikan dan pembelajaran. Program aplikasi teknologi pendidikan secara nasional yang pada awal perkembangannya dikoordinasikan oleh Pustekkom, sekarang ini telah menyebar, dan bahkan dapat dikatakan telah mulai melembaga. Hal ini terjadi karena telah banyaknya tenaga yang terdidik dalam bidang teknologi pendidikan dan banyaknya kegiatan penerapan teknologi pendidikan yang terintegrasi (imbedded) dalam kegiatan pendidikan atau pembelajaran. Program-program tersebut mempunyai skala dan tujuan yang berbeda-beda, seperti sistem belajar di rumah (home-schooling), SLTP/MTs Terbuka, SMU Terbuka, KEJAR Paket A, B, dan C, televisi pendidikan (serial pertama tentang pendidikan karakter, ACI = Aku Cinta Indonesia), TV Edukasi, penataran guru melalui siaran radio pendidikan, penggunaan berbagai strategi dan sumber belajar di sekolah maupun lembaga pelatihan, Universitas Terbuka, dll. Keseluruhan kegiatan ini sudah merupakan bagian integral dalam sistem pendidikan.

\section{PEMBAHASAN}

\section{Implikasi Instruksional Teknologi Pendidikan dalam Pembelajaran}

Teknologi pendidikan dalam pengajaran adalah kajian dan praktik untuk membantu proses belajar dan meningkatkan kinerja dengan membuat, menggunakan, dan mengelola proses dan sumber teknologi yang memadai. Para ahli teknologi pendidikan berpendapat bahwa peranan utama teknologi pendidikan adalah untuk membantu meningkatkan efisiensi yang menyeluruh dalam proses belajar mengajar.

Penerapan teknologi pendidikan dalam pendidikan hendaknya membuat proses pendidikan pada umumnya dan proses belajar mengajar pada khususnya lebih efisien, lebih efektive dan memberikan nilai tambah yang positif. Efektif dan efesien berarti upaya pendidikan yang dilakukan hendaknya dapat mencapai tujuan yang telah digariskan dengan sedikit mungkin mengeluarkan biaya, tenaga, dan waktu. Kondisi seperti tersebut di atas dimungkinkan karena teknologi pendidikan memiliki beberapa implikasi dalam pembelajaran diantaranya : ${ }^{9}$

a. Potensi teknologi pendidikan

Potensi sebagaimana yang dikemukakan oleh Ely dalam Sadiman sebagai berikut:

1) Meningkatkan produktivitas pendidikan dengan jalan : a) Mempercepat laju belajar; b) Membantu guru untuk menggunakan waktunya secara lebih baik; dan

${ }^{9}$ Salma Prawiladilaga, Dewi, Mozaik Pendidikan,( Jakarta: Kencana, 2004), hlm. 54. 
c) Mengurangi beban guru dalam menyajikan informasi, sehingga guru dapat lebih banyak membina dan mengembangkan kegairahan belajar anak. Dengan demikian guru akan lebih banyak berfungsi sebagai manajer pembelajaran.

2) Memberikan pendidikan yang sifatnya lebih individual dengan jalan: 1) Mengurangi kontrol guru yang kaku dan konvensional, 2) Memberikan kesempatan anak belajar secara maksimal, 3) Dapat melayani karakteristik individu yang berbeda-beda, karena adanya berbagai pilihan sumber belajar.

3) Memberikan dasar yang ilmiah pada pengajaran dengan jalan: 1) Perencanaan program pengajaran yang lebih sistimatis; dan 2) Pengembangan bahan pengajaran yang dilandasi penelitian tentang prilaku manusia.

4) Lebih memantapkan pengajaran dengan jalan: 1) Meningkatkan kemampuan guru dengan berbagai media komunikasi, dan 2) Penyajian data informasi secara lebih kongkrit.

5) Kemungkinan belajar secara seketika, karena dapat : 1) Mengurangi jurang pemisah antara pelajaran di dalam dan di luar sekolah, 2) Memberikan pengetahuan langsung apa yang ada di luar sekolah dapat dibawa masuk ke kelas.

b. Fungsi teknologi pendidikan

Adapun beberapa fungsi teknologi pendidikan yaitu :

1) Sebagai sarana bahan ajar yang ilmiah dan obyektif.

2) Sebagai sarana untuk memotifasi peserta didik yang semangat belajarnya rendah.

3) Sebagai sarana untuk membantu peserta didik mempresentasikan apa yang mereka ketahui

4) Sebagai sarana untuk meningkatkan efektifitas pembelajaran.

5) Sebagai sarana mempermudah penyampaian materi.

6) Sebagai sarana untuk mempermudah desain pembelajaran.

7) Sebagai media pendukung pelajaran dengan mudah

8) Sebagai sarana pendukung terlaksananya program pembelajaran yang sistematis

9) Sebagai sarana meningkatkan keberhasilan pembelajaran.

c. Manfaat Teknologi Pendidikan

Mengenai manfaat teknologi pendidikan dalam pembelajaran sangatlah banyak dan hal ini tergantung dari siapa yang memanfaatkannya. Berikut adalah beberapa manfaat dari teknologi pembelajaran bagi pendidik dan peserta didik:

1) Manfaat bagi pendidik

a) Pendidik dapat lebih memudahkan tercapainya tujuan pendidikan.

b) Pendidik dapat mempermudah desain pembelajaran.

c) Pendidik dapat menunjang metode pembelajaran. 
d) Pendidik dapat lebih meningkatkan efektifitas Pembelajaran.

e) Pendidik lebih mudah menyampaikan materi pembelajaran.

f) Pendidik dapat mengefisiensikan waktu.

g) Dapat menjadi daya dukung pengajaran seorang pendidik.

2) Manfaat bagi peserta didik

a) Peserta didik dapat lebih cepat menyerap materi pelajaran yang diberikan oleh pendidik.

b) Peserta didik menerima materi pembelajaran dengan senang.

c) Peserta didik dapat mempresentasikan apa yang mereka ketahui.

d) Peserta didik tidak bosan dengan cara penyampaian materi pembelajaran secara verbal.

d. Peran Teknologi Pendidikan Dalam Pembelajaran

Ada sejumlah peran dari memperkenalkan teknologi di bidang pendidikan. Telah ada dampak positif dari teknologi pada pendidikan. Dengan menggunakan potensi teknologi, kecepatan dan gaya belajar telah mengalami perubahan dan komunikasi telah menjadi lebih mudah.

Berikut adalah beberapa peranan dari teknologi pendidikan:

1) Salah satu peran teknologi pendidikan bagi siswa adalah bahwa hal itu membantu mereka meningkatkan kemampuan belajar mereka. Karena itu adalah salah satu bidang yang terus berubah.

2) Informasi dapat digambarkan dalam berbagai cara dengan bantuan bahan studi. Pengetahuan telah menjadi mudah diakses oleh siswa di setiap bagian dunia dengan penerapan teknologi di bidang pendidikan. Kelas online membantu siswa untuk berinteraksi dengan siswa lain milik aliran yang sama, tetapi terletak di tempat lain di dunia.

3) Karena Internet adalah media utama, maka siswa tidak harus membawa ransel yang berat penuh dengan buku. Mereka dapat berjalan dengan nyaman ke kelas di mana peralatan tersebut sudah ditempatkan.

e. Pengaruh Teknologi Pendidikan terhadap Proses Pembelajaran

1) Pengaruh positif :

a) menambah keanekaragaman pilihan sumber maupun kesempatan belajar.

b) menambah daya tarik, minat, dan motivasi untuk belajar.

c) menyebarkan informasi secara meluas, seragam, cepat, dan up to date.

d) pengajaran dan proses belajar mengajar lebih efektif.

e) mempunyai keuntungan rasio efektivitas biaya, bila dibandingkan dengan sistem tradisional.

f) memasyarakatnya pendidikan terbuka/jarak jauh.

2) Pengaruh negatif : 
a) kurangnya interaksi antara guru dan siswa.

b) berubahnya peran guru dari teknik pembelajaran konvensional menjadi ICT.

c) penyebab utama sikap malas karena kemudahan yang diberikan oleh teknologi.

d) otomatis berpengaruh dengan jiwa konsumeris dan menganggap teknologi adalah kebutuhan primer yang berpengaruh pada life style.

e) bersikap serba instan karena teknologi menyuguhkan hal yang serba instan.

f) sering disalah gunakan untuk melakukan kegiatan yang dianggap tak pantas dilakukan.

f. Macam-macam perangkat teknologi pendidikan yang digunakan sebagai bahan ajar maupun alat bantu pembelajaran diantaranya:

1) Cash Register : alat yang digunakan sebagai informasi pembayaran.

2) Calculator : alat yang digunakan untuk memperoleh informasi penghitungan angka.

3) Computer : perangkat berupa hardware dan software yang digunakan untuk membantu manusia dalam mengolah data menjadi informasi.

4) Laptop/ Notebook: perangkat canggih yang fungsinya seperti computer.

5) Deskbook : perangkat sejenis computer dengan bentuk yang praktis dimana CPU menyatu dengan monitor.

6) PDA (Personal Digital Assistant) : perangkat sejenis computer tetapi bentuknya sangat mini sehingga dapat dimasukan saku, bahkan sekarang ada yang berfungsi sebagai telepon genggam (PDA Phone).

7) Kamus Elektronik : perangkat elektronik yang digunakan menerjemahkan antar bahasa.

8) Alqur'an Digital : revolusi baru dalam dunia buku. Kitab suci Alqur'an kini tersedia dalam bentuk digital, lengkap dengan layar yang menampilkan tulisan dan suara.

\section{Pengembangan dalam Pendidikan Islam}

Implikasi instruksional teknologi pendidikan dalam proses pembelajaran dalam pendidikan Islam dapat terlihat dengan adanya beberapa program yang dikembangkan untuk dipakai dalam keefektifan proses belajar mengajar di antaranya; program elearning dan Ubiquitous computing.10

a. E-learning

Pengertian istilah e-learning menurut buku TIK oleh Munir: Huruf e pada e-learning berarti elektronik yang kerap disepadankan dengan kata virtual (maya) atau

${ }^{10}$ Munir, Kurikulum Berbasis Teknologi Informasi dan Komunikasi.( Bandung : Alfabeta, 2008). hlm. 78. 
distance (jarak). Dari sini kemudian muncul istilah virtual learning (pembelajaran di dunia maya) atau distance learning (pembelajaran jarak jauh). Kata learning sering diartikan dengan belajar pendidikan (education) atau pelatihan (training).

Jadi e-learning berarti pembelajaran dengan menggunakan media atau jasa bantuan perangkat elektronika (network) yang memungkinkan tersampaikannya bahan ajar kepada para peserta didik menggunakan media teknologi informasi berupa komputer dan jaringan internet atau intranet. Singkat kata, e-learning adalah proses learning (pembelajaran) menggunakan / memanfaatkan TIK sebagai tools.

Dengan e-learning, belajar dapat dilakukan di mana saja, kapan saja, melalui jalur mana saja dan dengan kecepatan akses apapun. Dalam pembelajaran e-learning pengajar dan peserta didik tidak perlu berada di tempat dan waktu yang sama untuk melangsungkan proses pembelajaran, e-learning memperpendek jarak antara pengajar dan peserta didik sehingga proses pembelajaran berlangsung secara efisien dan efektif.

Saat ini e-learning telah berkembang dalam berbagai model pembelajaran yang berbasis TIK seperti: CBT (Computer Based Training), CBI (Computer Based Instruction), Distance Learning, Distance Education, CLE (Cybernetic Learning Environment), Desktop Videoconferencing, ILS (Integrated Learning System), LCC (Learner-Centered Classroom), Teleconferencing, WBT (Web-Based Training).

\section{b. Ubiquitous computing}

Ubiquitous computing dapat didefinisikan sebagai penggunaan komputer yang tersebar di mana user berada. Sejumlah komputer disatukan dalam suatu lingkungan dan tersedia bagi setiap orang yang berada di lokasi tersebut. Setiap komputer dapat melakukan pekerjaan yang dipersiapkan untuk tidak banyak melibatkan intervensi manusia atau bahkan tanpa harus mendeteksi di mana pemakai berada. Ide ubiquitous computing pertama kali disampaikan oleh Mark Weiser di Laboratorium Komputer Xerox PARC, yang membayangkan komputer dipasangkan di dinding, di permukaan meja, di setiap benda sehingga seseorang dapat berkomunikasi dengan ratusan komputer pada saat yang sama. Setiap komputer secara tersembunyi diletakkan di lingkungan dan dihubungkan secara nirkabel.

Buxton menyatakan bahwa ubiquitous computing mempunyai karakteristik utama yaitu:

1) Ubiquity: interaksi tidak dilakukan oleh suatu saluran melalui satu workstation. Akses ke komputer dapat dilakukan di mana saja. Sebagai contoh, di suatu kantor ada puluhan komputer, layar display, dan sebagainya dengan ukuran bervariasi mulai dari tombol seukuran jam tangan, Pads sebesar notebook, sampai papan informasi sebesar papan tulis yang semuanya terhubung ke satu jaringan. Jaringan 
nirkabel akan tersedia secara luas untuk mendukung akses bergerak dan akses jarak jauh.

2) Transparency: teknologi ini tidak menganggu keberadaan pemakai, tidak terlihat dan terintegrasi dalam suatu ekologi yang mencakup perkantoran, perumahan, supermarket, dan sebagainya.

Ubiquitous adalah kebalikan dari dunia realitas virtual yang menempatkan manusia dalam dunia yang diciptakan komputer, ubiquitous computing memaksa komputer eksis di dunia manusia. Belajar dengan Ubiquitous computing: Perangkat komputer baru yang kecil, portabel, mobile, dan murah, diperkirakan akan menggantikan komputer dekstop. Dengan adanya perangkat baru ini, murid akan lebih mudah membawa perangkat informasi personal ke lapangan untuk membantu mengerjakan tugas dan bisa di bawa pulang, selain itu murid juga bisa meningkatkan kolaborasi dan memudahkan penggunaan tanpa di batasi lokasi.

Hubungan antara e-learning dengan ubiquitous computing: Seperti yang dapat kita baca di atas, baik e-learning maupun ubiquitous computing memiliki fungsi yang mirip, yaitu: mempermudah proses pembelajaran. Hal ini terlihat dari adanya kuliah on-line (audio conferencing, video broadcasting, dan video conferencing) di mana mahasiswa dan dosen berada di negara yang berbeda dan di benua yang berbeda, mahasiswa tidak perlu lagi meninggalkan tanah airnya untuk mengikuti kuliah dari universitas yang ditujunya.

\section{PENUTUP}

Dari uraian dalam analisa permasalahan dapat disimpulkan bahwa perkembangan Teknologi Modern atau teknologi informasi memacu suatu cara baru dalam kehidupan, dari kehidupan dimulai sampai dengan berakhir, kehidupan seperti ini dikenal dengan $e$ life, artinya kehidupan ini sudah dipengaruhi oleh berbagai kebutuhan secara elektronik.

Banyak yang meramalkan bahwa pendidikan masa mendatang akan bersifat luwes (flexible), terbuka, dan dapat diakses oleh siapapun juga yang memerlukan tanpa pandang faktor jenis, usia, maupun pengalaman pendidikan sebelumnya. Pendidikan mendatang akan lebih ditentukan informasi interaktif, seperti CD-ROM Multimedia, dalam pendidikan secara bertahap menggantikan TV dan Video. Dengan adanya perkembangan teknologi informasi dalam bidang pendidikan, maka pada saat ini sudah dimungkinkan untuk diadakan belajar jarak jauh dengan menggunakan media internet untuk menghubungkan antara mahasiswa dengan dosennya, melihat nilai mahasiswa secara online, mengecek keuangan, melihat jadwal kuliah, mengirimkan berkas tugas yang diberikan dosen dan sebagainya, semuanya itu sudah dapat dilakukan

Namun dari peran teknologi Modern dalam pendidikan, tidak sepenuhnya teknologi 
FITRAH Vol. 01 No. 2 Juli-Desember 2015

berperan positif, tetapi ada pula pengaruh negatif dari teknologi modern yang digunakan dalam proses pembelajaran. Untuk itu dibutuhkan tenaga pendidik yang dapat memilih dan memilah media serta penggunaan yang selektif dalam pembelajaran. Sehingga teknologi modern dalam proses pembelajaran dapat memberikan peran dan manfaat yang optimal demi mencapai tujuan pendidikan dengan baik. 


\section{DAFTAR PUSTAKA}

AECT, The Definition Of Educational Technology, Washington,D.C.,USA: Association for Educational Communications and Technology, 2004.

Banathy, Bela H, System Design in Education : a journey to create the future, Englewood Cliffs NJ: Educational Technology Publications, 1991.

Nasution. N, Teknologi Pendidikan, Jakarta: Bumi Aksara, 2008.

Ma'mur Asmani, Teknologi Informasi dan Komunikasi dalam Dunia Pendidikan. Jogjakarta: Diva Press, 2011

Miarso dan Yusufhadi, Menyemai Benih Teknologi Pendidikan, Jakarta: Pustekkom bekerjasama dengan Kencana, 2004.

Munir, Kurikulum Berbasis Teknologi Informasi dan Komunikasi, Bandung: Alfabeta, 2008.

Salma Prawiladilaga dan Dewi, Mozaik Pendidikan, Jakarta: Kencana, 2004.

Seels, Babara B. and Rita C. Richey, Instructional Technology: The Definition and Domains of the Field. Washington DC : AECT, 1994.

Sudjarwo, Teknologi Pendidikan. Surabaya: Erlangga, 1984. 
FITRAH Vol. 01 No. 2 Juli-Desember 2015

Gangguan - Gangguan Dalam Psikologi Sosial Dan Keagamaan 